\title{
Structure of Oxidative and Sulphate-Clorinating Roasting Products of Nickel Converter Matte ${ }^{1}$
}

\author{
E. N. Selivanov ${ }^{a, *}$, R. I. Gulyaeva ${ }^{a, * *}$, D. A. Toloknov ${ }^{a, * * *}$, \\ A. S. Avdeev ${ }^{b * * * * *}$, and S. V. Kniss ${ }^{c}, * * * * *$ \\ ${ }^{a}$ Institute of Metallurgy, Ural Branch, Russian Academy of Sciences, 101, Amundsen St., Yekaterinburg, 620016 Russia \\ ${ }^{b}$ Ufaleynickel JSC, 1, Pobedy St., Verkhnii Ufalei, Sverdlovsk region, 456800 Russia \\ ${ }^{c}$ Ural Federal University, 19, Mira St., Yekaterinburg, 620002 Russia \\ *e-mail:pcmlab@mail.ru \\ **e-mail:gulroza@mail.ru \\ ***e-mail: toloknovda@mail.ru \\ ****e-mail:pto@ufalynickel.ru \\ *****e-mail: bt_work@mail.ru
}

\begin{abstract}
The structure and phase composition of the nickel converter matte roasting products has been studied in the sulphate-chlorinating process stage. In stages of the converter matte oxidation in the "fluidized bed" and flash smelting remainder roasting together with silvinite the distribution of non-ferrous metals on the phase constituents has been estimated. In the article data from optical spectroscopy, as well as X-ray diffraction, microprobe and chemical analyze are used. As following from the composition of the phases formed during sulphate-chlorinating roasting and thermodynamic modeling data a number of reactions proceeding in the process is presented.
\end{abstract}

DOI: $10.3103 / \mathrm{S} 1067821213060266$

\section{INRODUCTION}

Nickel converter matte purification from copper is performed by means of sulphate-chlorinating roasting followed by leaching of copper compounds in "Ufaleynickel" JSC. The technology of processing includes slow-cooling and grinding of converter matte, oxidation in the flash smelter (FB), sulphate-chlorinating roasting of product oxidized partially, cake leaching with the copper transfer in solution, roasting of cake in a tube furnace and recovery smelting of nickel oxide to metal. During sulphate-chlorinating roasting stage copper passes into sulphates and chlorides dissolved in sulfuric acid dilute solutions. Chlorinating agents are sodium chloride or potassium chloride, gaseous chlorine and hydrogen chloride. As chlorinator $(\mathrm{NaCl})$ technical salt are used in "Ufaleynickel" Ltd. Roasting is subjected Converter matte nickel contenting 7678 pct. of nickel and copper less than 3 pct. Involvement in the technological cycle of copper high content raw materials as well as the use of copper-containing sulphidizer in melting process stage results in an increase in the $\mathrm{Cu} / \mathrm{Ni}$ ratio in converter matte. In order to process nickel convertor matte with a copper content of 4-5 pct. ( NaCl) chlorinator feed is necessary to increase, which leads to the formation of lowmelting eutectics and requires technological control

\footnotetext{
${ }^{1}$ The article was translated by the authors.
}

change because of the crust formation. For appropriate adjustments of equipment operation during sulphate-chlorinating roasting representations about the structure and phase composition of the products obtained during the processing of nickel convertor matte are important.

The purpose of this investigation is to study the structure and phase composition of sulphate-chlorinating roasting process stage products of nickel converter matte as well as estimate the distribution of nonferrous metals on the phase components.

\section{METHODS}

The phase composition and structure of the samples has been estimated by means of (NEOPHOT-2 software SIMAGIC) optical microscopy method, X-ray diffraction (XRPA) method by diffractometer in $\mathrm{Co} K_{\alpha}$ radiation followed by identification of phases in PDF database, electron microprobe (EPMA) by JSM-5900LV spectrometer, (HITACHI-Z8000, SPECTROFLAME) chemical analyzes. Thermal properties of the samples have been studied by NETZSCH STA 449C Jupiter analyzer, allowing to fix thermal effects by scanning calorimetry method and mass change.

The initial materials have been taken industrial samples of "Ufaleynickel" JSC, nickel converter matte containing, pct.: $74.3 \mathrm{Ni}, 3.24 \mathrm{Cu}, 0.12 \mathrm{Co}$, 
Table 1. Phase compositions in the points of local probing of the FB remainder (from Fig. 3)

\begin{tabular}{|c|c|c|c|c|c|c|c|}
\hline \multirow{2}{*}{ No. } & \multicolumn{6}{|c|}{ Content, wt \% } & \multirow{2}{*}{ Phase } \\
\hline & $\mathrm{S}$ & $\mathrm{Fe}$ & $\mathrm{O}$ & $\mathrm{Ni}$ & $\mathrm{Cu}$ & As & \\
\hline 1 & $22.9-24.8$ & $0.15-0.24$ & - & $68.6-71.6$ & $1.4-3.5$ & $6.0-6.3$ & $\mathrm{Ni}_{3} \mathrm{~S}_{2}$ \\
\hline 2 & - & $0.22-4.13$ & $19.2-21.3$ & $74.9-77.5$ & 0.51 & 0.02 & $\mathrm{NiO}$ \\
\hline 3 & $14.7-20.3$ & 0.16 & - & $2.9-3.9$ & $73.0-80.0$ & - & $\mathrm{Cu}_{2} \mathrm{~S}$ \\
\hline 4 & $20.9-22.3$ & $0.07-0.14$ & - & $19.1-43.6$ & $33.2-57.8$ & $0.31-1.84$ & $\mathrm{Cu}_{2} \mathrm{~S}-\mathrm{Ni}_{3} \mathrm{~S}_{2}$ \\
\hline 5 & 0.05 & 0.12 & - & 93.6 & 6.1 & - & $\mathrm{Ni}-\mathrm{Cu}$ \\
\hline
\end{tabular}

$0.32 \mathrm{Fe}, 16.8 \mathrm{~S}$; residue of flash smelter consists of $73.6 \mathrm{Ni}, 2.67 \mathrm{Cu}, 0.34 \mathrm{Co}, 0.38 \mathrm{Fe}, 1.07 \mathrm{~S}$, and 0.47 $\mathrm{SO}_{4}^{2-}$; residue chlorinated is $62.0 \mathrm{Ni}, 2.55 \mathrm{Cu}, 0.14 \mathrm{Co}$, $0.40 \mathrm{Fe}, 0.71 \mathrm{~S}, 2.27 \mathrm{SO}_{4}^{2-}, 5.10 \mathrm{Na}^{+}, 2.65 \mathrm{Cl}^{-}$.

\section{RESULTS}

Nickel converter matte corresponds closely to $\mathrm{Ni}(\mathrm{Cu})-\mathrm{N}_{3} \mathrm{~S}_{2}-\mathrm{Cu}_{2} \mathrm{~S}$ system. It is not purely a sulfide intermediate product inherently [3-5], non-ferrous metals are distributed both between sulfide $\left(\mathrm{Ni}_{3} \mathrm{~S}_{2}\right.$, $\left.\mathrm{Cu}_{2-x} \mathrm{~S}\right)$ and metal $(\mathrm{Cu}-\mathrm{Ni})$ solutions and the oxide components such as iron-nickel spinel $\left(\mathrm{Ni}_{x} \mathrm{Fe}_{2-x} \mathrm{O}_{4}\right)$ that has high content of cobalt (2-4.5 pct.). Spinel formation is likely to be due to delamination processes incompleteness of converting products and selection of oxide phases during crystallization [4]. The distribution of copper in several components greatly prevents to the search of conditions for its removal. According to [4] and the size of the metal sulphide phases formed during crystallization (rate cooling is $10 \mathrm{~K} / \mathrm{min}$ ) is $50-100 \mu \mathrm{m}$ for $\mathrm{Ni}_{3} \mathrm{~S}_{2}, 20-50 \mu \mathrm{m}$ for $\mathrm{Cu}_{1.96} \mathrm{~S}, 20-1000 \mu \mathrm{m}$ for $\mathrm{Ni}$. It should be noted the phases having formed contain a significant content of impurity elements. Nickel sulfide contains up to 0.4 pct. of $\mathrm{Co}, 0.5$ of $\mathrm{Cu}$ and 0.94 pct. of Fe. Copper sulfide contains $1.0-2.5$ pct. of $\mathrm{Ni}, 0.03-0.1$ of $\mathrm{Co}$ and 0.2 pct. of Fe. The metal component consists of nickel (70-95 pct.), copper (3-27), cobalt (1.0-1.2) and iron (0.5-1.0 pct.). Above impurities influence both the unit cell parameters and the properties exhibited by converter matte during heating in an oxidative atmosphere. Oxidation having crystallized and milled (up to $1 \mathrm{~mm}$ ) of converter matte is initially accompanied by formation of sulfates then oxidation together with sulfur dioxide gassing and the decomposition of sulfates $[4,6]$. In the case the reactions are proceeded $[1,2]$

$$
\begin{gathered}
2 \mathrm{Ni}_{3} \mathrm{~S}_{2}+7 \mathrm{O}_{2}=6 \mathrm{NiO}+4 \mathrm{SO}_{2}, \\
2 \mathrm{Ni}+\mathrm{O}_{2}=2 \mathrm{NiO}, \\
\mathrm{Cu}_{2} \mathrm{~S}+2 \mathrm{O}_{2}=2 \mathrm{CuO}+\mathrm{SO}_{2} .
\end{gathered}
$$

According to XRPA data (Fig. 1) the main phase component of cinder after roasting is nickel oxide, nickel metal reflexes were not identified. Reflexes of nickel sulfide [7] point out the incompleteness of its oxidation. As following from the sulfur content in the initial converter matte and roasting products desulfurization is about 95 pct.

Microscopic analysis has showed (Fig. 2) the flash smelter cinder consists of mainly hollow particle and its size varies from $300-500$ to 2000 micron. On the surface of the largest particles an oxide of nickel is identified while inside the nickel sulfide (10-100 micron) and copper (1-5 micron) areas are detected. Study detailed of the surface of the section by EPMA the dominate formation of nickel oxide with inclusions of nickel sulfides grains and copper also metallic phase has been confirmed (Fig. 3). It is shown copper sulfide particles and the metallic phase grain with size of particle up to $10 \mu \mathrm{m}$ is in inside unoxidized nickel sulfide.

Composition of nickel oxide is close to stoichiometric due to the low solubility of impurities. Nickel oxide phase (Table 1) has a relatively low copper content (about 0.5 pct.) and does not contains arsenic (less than 0.02 pct.). In unoxidized nickel sulfide particles it is detected up to 6.3 pct. of As and 1.373.5 pct. of $\mathrm{Cu}$, which exceed the original copper content in the nickel sulfide in 3-7 times.

The metallic nickel-based component contains up to 6.1 pct. of copper, which corresponds to $\mathrm{Ni} / \mathrm{Cu}$ ratio about 15 . In additional to metallic copper crystals formed due to eutectoid decomposition of $\mathrm{Cu}_{2} \mathrm{~S}$ and the sulfide components such as solid solutions based on $\mathrm{Cu}_{2} \mathrm{~S}$ and $\mathrm{Ni}_{3} \mathrm{~S}_{2}$ have been revealed.

After sulphate-chlorinating roasting cinder particles have a more complicated structure but the main phase is nickel oxide (Fig. 1). In additional to $\mathrm{NaCl}$ and $\mathrm{CuCl}$ is identified according to reflections on a relatively low intensity. The microstructure investigation (Fig. 4) has showed the calcine chlorinated consists of predominantly spongy finely and hollow particles of nickel oxide (from 100 to $700 \mu \mathrm{m}$ ). In the sample along with large entities nickel oxide fine particles are identified, its size achieving up to 5-10 $\mu \mathrm{m}$. Large particles have a pronounced layered structure. In the 


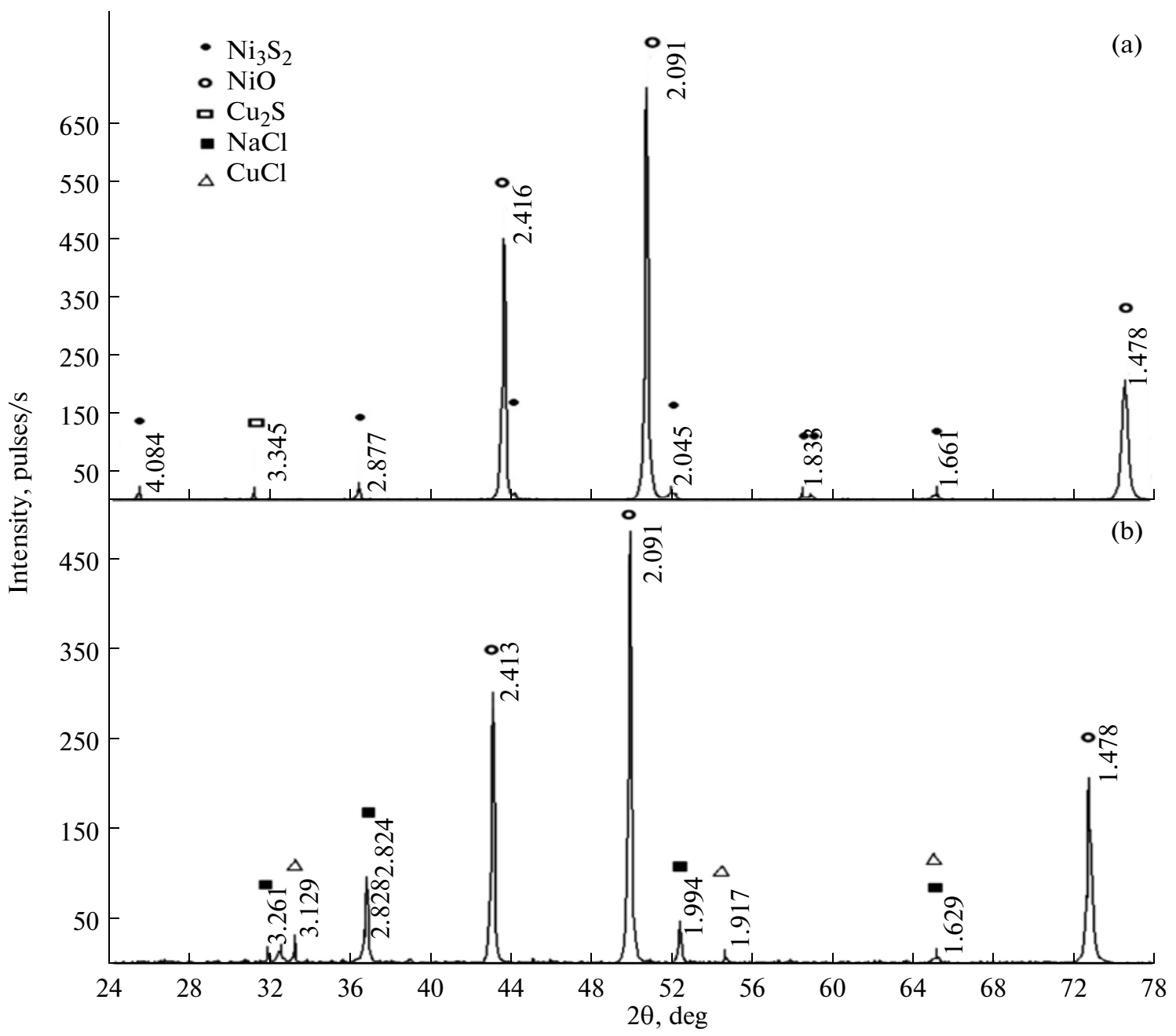

Fig. 1. X-ray diffraction pattern of the remainder (a) after oxidation in the flash furnaces and (b) after sulfate-chlorinating roasting.
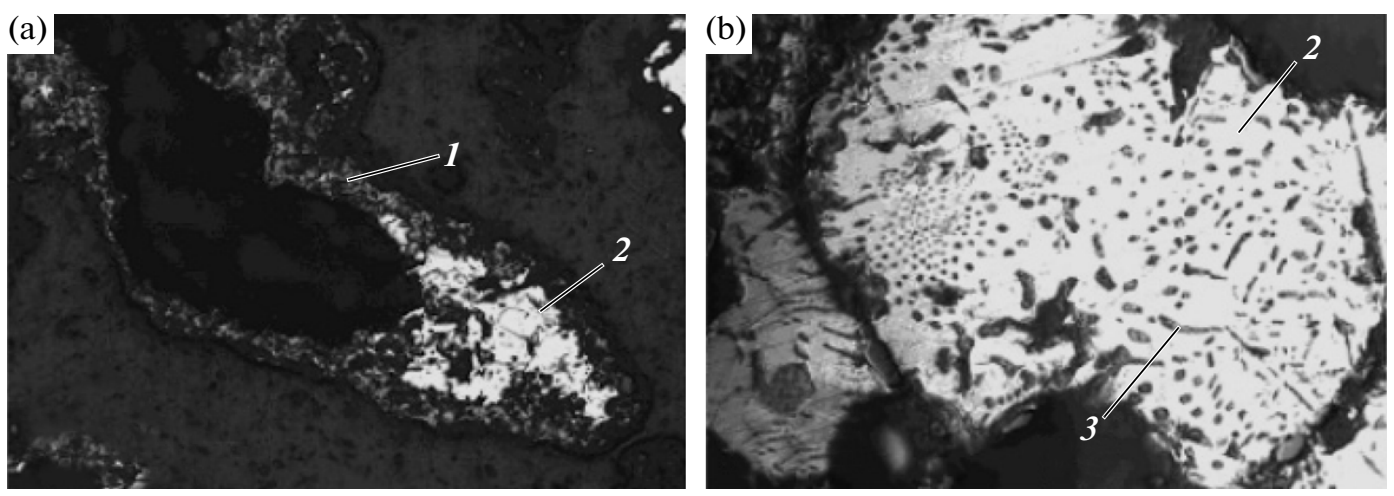

Fig. 2. Microstructure of the $\mathrm{FB}$ remainder (1) $\mathrm{NiO}$, (2) $\mathrm{Ni}_{3} \mathrm{~S}_{2}$, and (3) $\mathrm{Cu}_{2} \mathrm{~S}$. Magnification (a) $\times 100$ and (b) $\times 500$. 

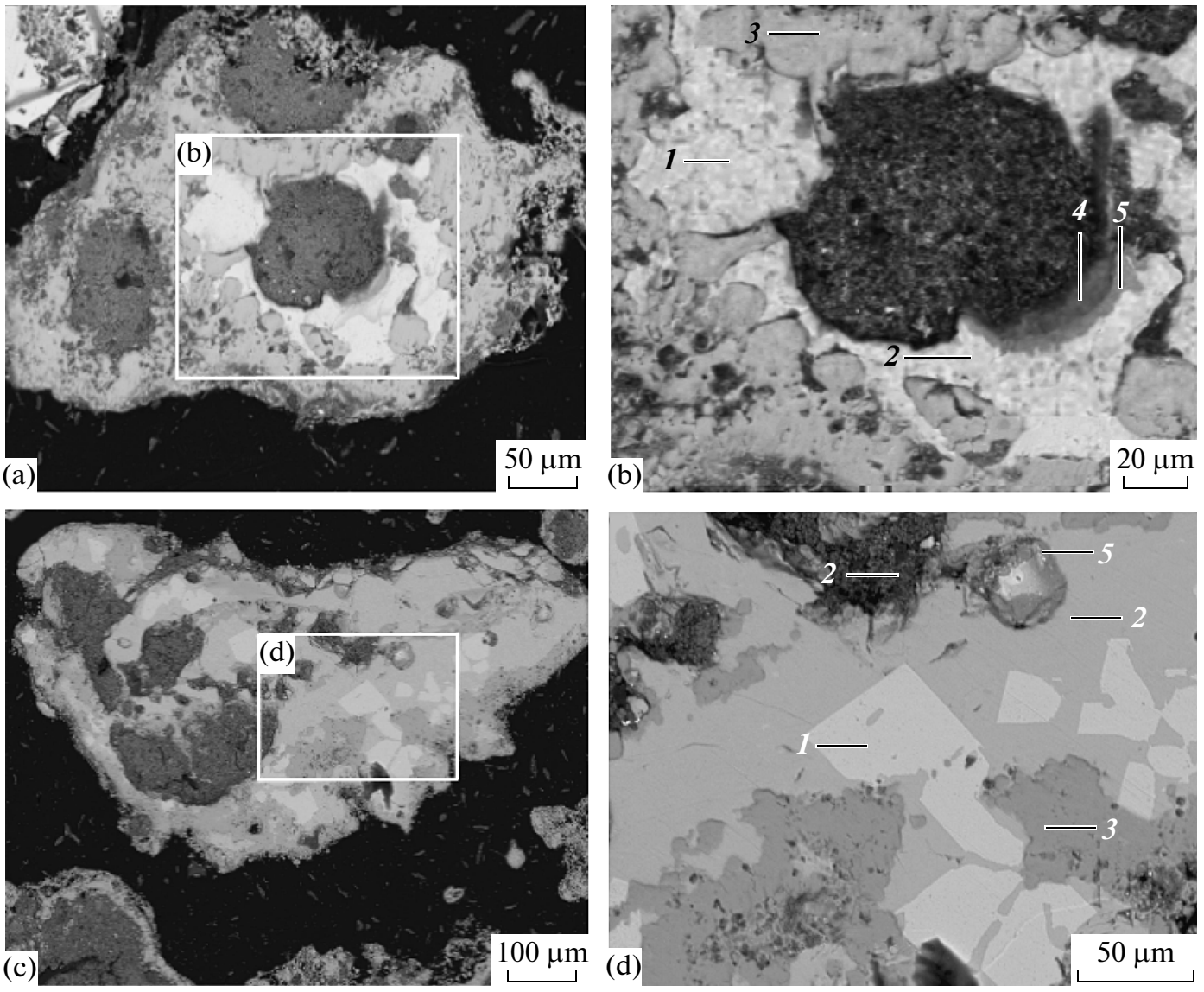

Fig. 3. Microstructure of the FB remainder and the local probing point of the phases.
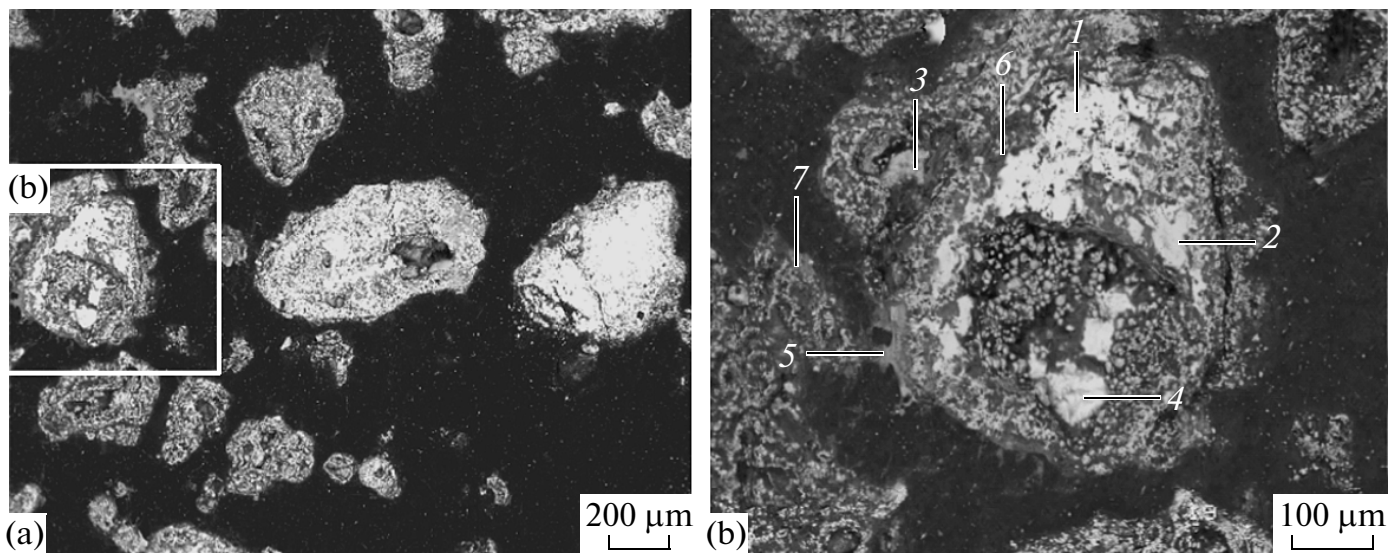

Fig. 4. Microstructure of the chlorinated remainder and the local probing point of the phases.

centers sulfides of nickel and copper surrounded by the nickel oxide and metal component are located. The surface of particles is represented by layer $(\mathrm{CuCl}$, $\mathrm{NiCl}_{2}, \mathrm{NaCl}$ ). As well as previous sample (calcine after oxidative roasting of converter matte) nickel oxide phase has a copper content relatively low.
The mixture of chlorides formed during roasting has $\mathrm{Cu} / \mathrm{Ni}$ ratio in the range of $0.7-0.8$, which is a half orders of magnitude higher than in the initial converter matte. Therefore, even though amount of salt phase formed during thermal treatment of remainder together with the sylvinite mixture is a small a chlori- 
Table 2. Phase compositions in the points of local probing the chlorinated remainder (from Fig. 5)

\begin{tabular}{c|c|c|c|c|c|c|c|c|c|l}
\hline \multirow{2}{*}{ No. } & \multicolumn{7}{|c|}{ Content, wt \% } & \multicolumn{2}{|c}{ Phase } \\
\cline { 2 - 8 } & $\mathrm{S}$ & $\mathrm{Fe}$ & $\mathrm{O}$ & $\mathrm{Ni}$ & $\mathrm{Cu}$ & $\mathrm{Na}$ & $\mathrm{Cl}$ & $\mathrm{Co}$ & $\mathrm{As}$ & \\
\hline 1 & 0.01 & 0.08 & - & 88.3 & 10.6 & 0.12 & - & 0.04 & 0.60 & $\mathrm{Ni}-\mathrm{Cu}$ \\
2 & 19.3 & 0.06 & - & 69.1 & 10.5 & 0.34 & 0.41 & 0.03 & 0.21 & $\mathrm{Ni}_{3} \mathrm{~S}_{2}-\mathrm{Cu}_{2} \mathrm{~S}$ \\
3 & 0.03 & 0.49 & 20.9 & 76.4 & 1.2 & - & 0.40 & 0.62 & 0.31 & $\mathrm{NiO}$ \\
4 & 23.2 & 0.06 & - & 45.7 & 29.6 & 0.79 & 0.30 & - & 0.15 & $\mathrm{Ni}_{3} \mathrm{~S}_{2}-\mathrm{Cu}_{2} \mathrm{~S}$ \\
5 & 1.3 & 0.33 & - & 6.40 & 49.8 & 5.30 & 35.0 & 0.24 & 0.05 & $\mathrm{CuCl}_{2} \mathrm{NaCl}$ \\
6 & 0.40 & 1.4 & 19.1 & 46.8 & 15.8 & 12.6 & 1.12 & 0.08 & 0.20 & $\mathrm{Ni}(\mathrm{Cu}) \mathrm{O}, \mathrm{Na}_{2} \mathrm{O}$ \\
7 & 1.84 & 6.7 & - & 38.6 & 21.9 & 10.2 & 15.8 & 0.32 & 0.13 & $\mathrm{NiCl} 2, \mathrm{CuCl}, \mathrm{NaCl}_{2} \mathrm{Na}_{2} \mathrm{SO}_{4}$ \\
\hline
\end{tabular}

Table 3

\begin{tabular}{l|c|c|c|c|c|c|c|c}
\hline Compound & $\mathrm{NiCl}_{2}$ & $\mathrm{CuCl}$ & $\mathrm{CuCl}_{2}$ & $\mathrm{FeCl}_{3}$ & $\mathrm{FeCl}_{2}$ & $\mathrm{CoCl}_{2}$ & $\mathrm{AsCl}_{3}$ & $\mathrm{AsCl}_{5}$ \\
\hline$t_{\mathrm{m}},{ }^{\circ} \mathrm{C}$ & 1001 & 426 & 498 & 306 & 677 & 735 & -16.2 & -40 \\
$t_{\mathrm{b}},{ }^{\circ} \mathrm{C}$ & 1627 & 1490 & 993 & 315 & 1026 & 1049 & 130 & - \\
\hline
\end{tabular}

nation of copper is possible sufficiently. In the above sample chlorination of copper has proceeded not fully due to the c raw material features, namely, a thin impregnation of copper sulfide and metal in nickel sulfide.

According to thermal analysis data of the cinder after sulphate-chlorinating roasting (Fig. 5) the heating of the sample is accompanied by a number of exo-and endothermic effects connected with phase transitions for $\mathrm{NaCl}, \mathrm{KCl}-\mathrm{CuCl}_{2}, \mathrm{NiCl}_{2}, \mathrm{CuCl}_{2}-\mathrm{K}_{2} \mathrm{O}$, and $\mathrm{Na}_{2} \mathrm{O}[9,10]$. The phase transition at $406.8^{\circ} \mathrm{C}$ corresponds to peritectic transformation proceeding to form $\alpha-\mathrm{CuCl}_{2}$ in the system $\mathrm{KCl}-\mathrm{CuCl}_{2}$, and conversion of nickel sulfide in high temperature modification is the case at 525.2/530.1. The change in mass of the sample during heating and thermal effects related can be explained by sublimation of chlorides [9]. The melting and boiling point of chlorides which form in the process have the values (Table 3 ).

Behavior of arsenic during oxidative and sulphatechlorinating roasting is drawn attention. Given during oxidation in FB arsenic is oxidized to a lesser degree (compared with sulfur) during sulphate-chlorinating roasting of phases containing arsenic up to 1 pct. is not detected. Above speaks about its chlorination is accompanied by passing in gas phase.

As following from the obtained data and the ability of sodium chloride to decompose to forming gaseous chlorine in sulfur dioxide atmosphere $[1,2,11,12]$ it is result from the main reactions for sulphate-chlorinating roasting are

$$
\begin{gathered}
\mathrm{NaCl}+0.5 \mathrm{SO}_{2}+0.5 \mathrm{O}_{2}=0.5 \mathrm{Na}_{2} \mathrm{SO}_{4}+0.5 \mathrm{Cl}_{2} \\
\mathrm{NiO}+\mathrm{Cl}_{2}=\mathrm{NiCl}_{2}+0.5 \mathrm{O}_{2} \\
\mathrm{CuO}+\mathrm{Cl}_{2}=\mathrm{CuCl}_{2}+0.5 \mathrm{O}_{2} \\
\mathrm{CuO}+0.5 \mathrm{Cl}_{2}=0.5 \mathrm{CuCl}+0.5 \mathrm{O}_{2} \\
\mathrm{Cu}_{2} \mathrm{O}+\mathrm{Cl}_{2}=2 \mathrm{CuCl}+0.5 \mathrm{O}_{2} \\
\mathrm{Ni}_{3} \mathrm{~S}_{2}+3 \mathrm{Cl}_{2}=3 \mathrm{NiCl}_{2}+\mathrm{S}_{2} \\
\mathrm{Cu}_{2} \mathrm{Cl}+\mathrm{Cl}_{2}=\mathrm{CuCl}+0.5 \mathrm{~S}_{2}
\end{gathered}
$$

Thermodynamic estimation [13] of interactions (4)(10) in the temperature range from 273 to $1273 \mathrm{~K}$ (Fig. 6) pointed out the negative values of free energy Gibbs (for 1 mole of the starting materials), which indicates a high probability of their run. Reaction (9) runs slowly enough [2], however, in the presence of copper chloride and iron an interactions take place.

$$
\begin{gathered}
\mathrm{Ni}_{3} \mathrm{~S}_{2}+\mathrm{CuCl}_{2}=\mathrm{CuCl}+\mathrm{NiCl}_{2}+\mathrm{S}_{2} \\
\mathrm{Ni}_{3} \mathrm{~S}_{2}+6 \mathrm{FeCl}_{3}=3 \mathrm{NiCl}_{2}+6 \mathrm{FeCl}_{2}+\mathrm{S}_{2} .
\end{gathered}
$$

Reaction (11) explains reflexes of copper chloride $(\mathrm{CuCl})$ in the diffraction pattern of calcine chlorinated (Fig. 1).It should be noted the amount of nickel in the soluble forms is $1-2$ pct. [14]. 


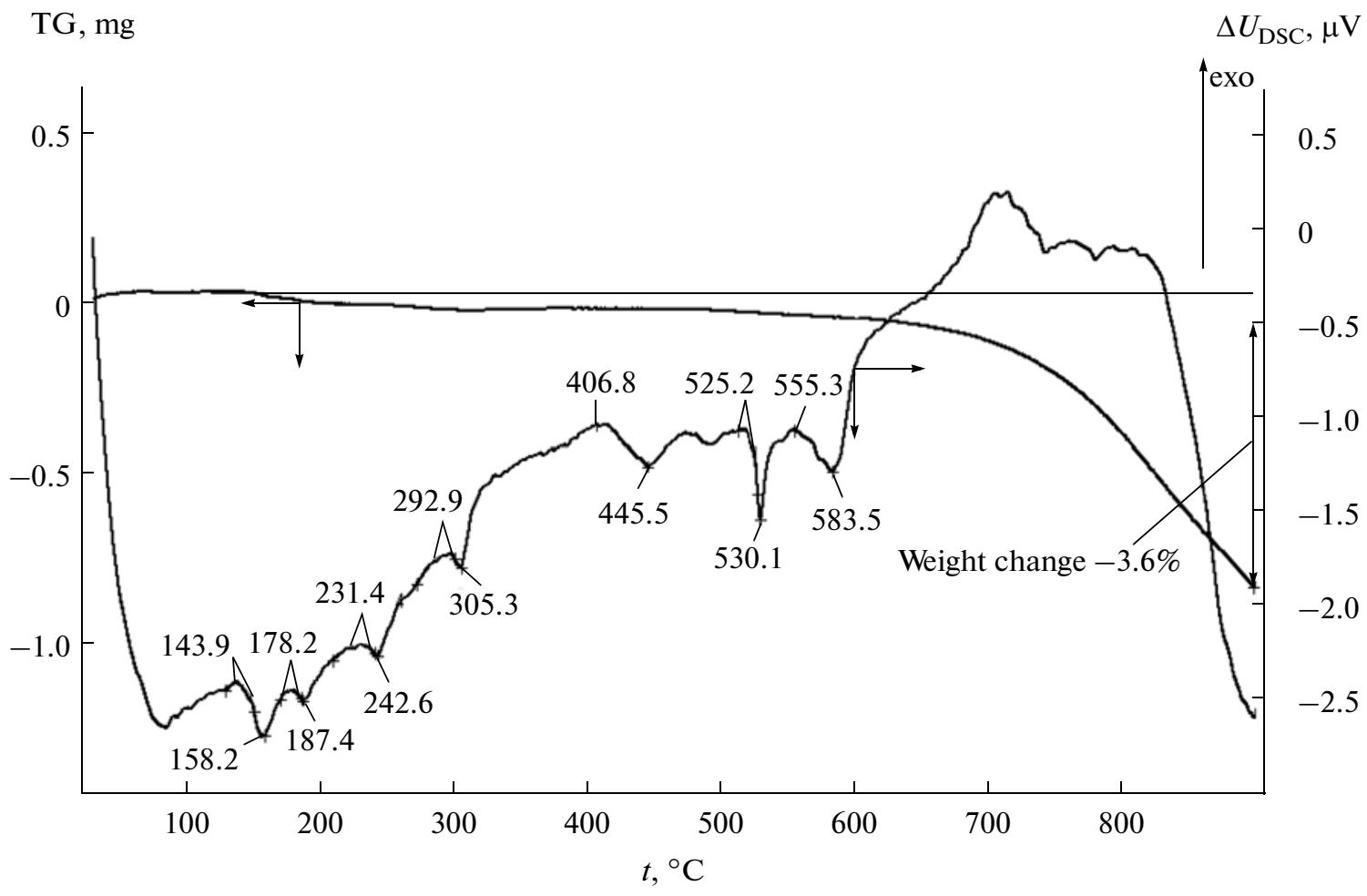

Fig. 5. Thermogram of the chlorinated ash upon heating $(10 \mathrm{~K} / \mathrm{min})$ in the argon flow. DSC is differential scanning calorimetry.

Thermodynamic analysis of direct interaction the reactions of potassium chloride or sodium with oxides and sulfides of nonferrous metals in the temperature range $273-1273 \mathrm{~K}$ indicates the positive values of the Gibbs energy, which point out impossibility under the conditions.

Gas phase composition influences significantly the mechanism oxidized cinder chlorination. In sulfur

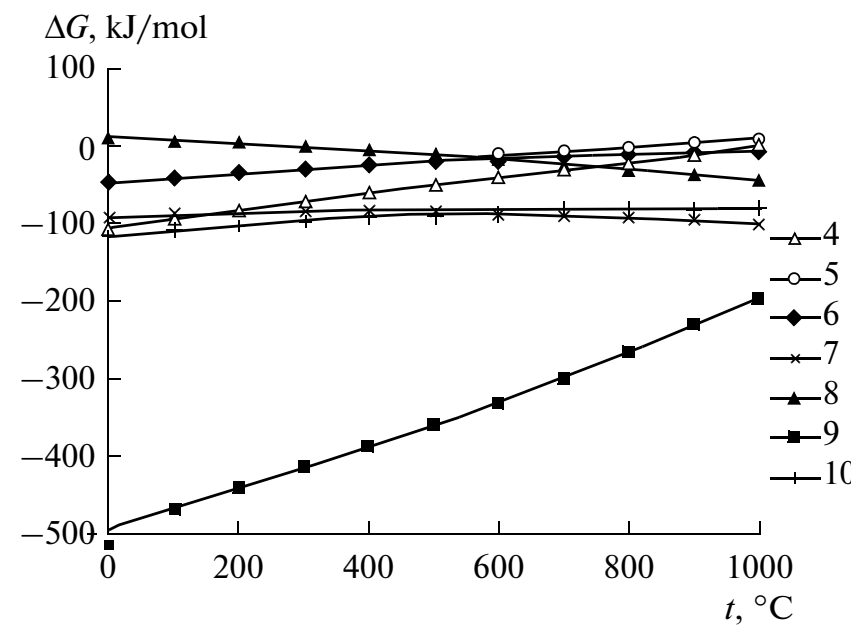

Fig. 6. Variation in the isobaric-isothermal potential of reactions (4)-(10) with temperature. dioxide (sulfur trioxide) chlorinator is decomposed with formation of sodium (or potassium) sulfate and gaseous chlorine being a chlorinating agent.

\section{CONCLUSIONS}

The basic phase components are detected and the structure of the samples obtained during converter matte processing in oxidation stages in flash furnaces and sulphate-chlorinating roasting is revealed. As following from composition of the phases formed during sulphate-chlorinating roasting and thermodynamic simulation data the sequence of reactions occurring during the roasting is shown.

It has been shown in oxidized remainder main phase is nickel oxide and copper is concentrated in the form of oxide, sulfide and metal. After sulphate-chlorinating roasting of the copper part passes into chlorides $\left(\mathrm{CuCl}, \mathrm{CuCl}_{2}\right)$.

To achieve high performance in the purification of nickel converter matte from copper by sulphate-chlorinating roasting method followed by leaching it is necessary to form a large phase sufficiently of copper sulfide (at least $20-50 \mu \mathrm{m}$ ) during the cooling and crystallization step of nickel converter matte, its break down by means of converter matte grinding in preparation to roasting and complete oxidation to $\mathrm{Cu}_{2} \mathrm{O}$ $(\mathrm{CuO})$. 


\section{ACKNOWLEDGMENTS}

This study was supported by the Ministry of Education and Science of the Russian Federation, state contract no. 02.740.11.0821.

\section{REFERENCES}

1. Pimenov, L.I. and Mikhailov, V.I., Pererabotka okislennykh nikelevykh rud (Processing of Oxidized Nickel Ores), Moscow: Metallurgiya, 1972.

2. Reznik, I.D., Ermakov, G.P., and Shneerson, Ya.M., Nikel' (Nickel), Moscow: Nauka Tekhnol., 2003, vol. 3.

3. Pimenov, L.I., Klement'ev, V.V., and Khokhlov, O.I., in Ufalei-Rodina rossiiskogo nikelya (Ufalei-the Fatherland of Russian Nickel), Chelyabinsk: Kniga, 1993, p. 176.

4. Selivanov, E.N., Gulyaeva, R.I., Nechvoglod, O.V., et al., Metally, 2009, no. 2, p. 8.

5. Klement'ev, V.V., Pimenov, L.I., and Grigor'eva, V.N., Tsvetn. Met., 1978, no. 9, p. 22.

6. Asaki, A., Hajika, K., and Kondo, Y., Metall. Mater. Trans. B, 1984, vol. 15, no. 1, p. 127.

7. Power diffraction files, nos.: 00-030-0863, 01-0784793, 01-078-4374, 01-070-2509, 01-081-1841.
8. Udoeva, L.Yu., Gulyaeva, R.I., Selivanov, E.N., et al., in Trudy X Mezhdunarodnogo simpoziuma "Uporyadochenie $v$ metallakh $i$ splavakh" (Proc. X Int. Symp. "Ordering in Metals and Alloys), Rostov-on-Don: South Federal Univ., 2007, vol. 2, p. 181.

9. Morozov, I.S., Primenenie khlora v metallurgii redkikh $i$ tsvetnykh metallov (Application of Chlorine in Metallurgy of Rare and Nonferrous Metals), Moscow: Nauka, 1966.

10. Diagrammy plavkosti solevykh sistem. Ch. 1: Spravochnik (Melting Diagrams of Salt Systems. Part 1: Handbook) Posypaiko, V.I. and Alekseeva, E.A, Eds., Moscow: Metallurgiya, 1977.

11. Pimenov, L.I. and Reznik, I.D., in Ufalei-rodina rossiiskogo nikelya (Ufalei-the Fatherland of Russian Nickel), Chelyabinsk: Kniga, 1993, p. 197.

12. Vanyukov, A.V. and Utkin, N.I., Kompleksnaya pererabotka mednogo i nikelevogo syr'ya (Complex Processing of the Copper and Nickel Ore Mateirals), Chelyabinsk: Metallurgiya, 1988.

13. Roine, A., Outokumpu HSC Chemistry for Windows. Chemical Reactions and Equilibrium Software with Extensive Thermochemical Database. Pori: Outokumpu research OY, 2002.

14. Klement'ev, V.V., Pimenov, L.I., Konygin, V.P., et al., in Ufalei-rodina rossiiskogo nikelya (Ufalei-the Fatherland of Russian Nickel), Chelyabinsk: Kniga, 1993, p. 181. 